\title{
Molecular Method of Detection of Primary Endodontic Infection- An Ex Vivo Study
}

\author{
Shruthi H. Attavar ${ }^{1}$, Mithra N. Hegde 2 , Veena Shetty ${ }^{3}$, Chaithra ${ }^{4}$
}

${ }^{1}$ Department of Conservative and Endodontics, A B Shetty Memorial Institute of Dental Sciences, NITTE (Deemed to be University) Mangalore, Karnataka, India. ${ }^{2}$ Department of Conservative and Endodontics, A B Shetty Memorial Institute of Dental Sciences, NITTE (Deemed to be University) Mangalore, Karnataka, India. ${ }^{3}$ Department of

Microbiology, K S Hegde Medical College, NITTE (Deemed to be University), Ullal, Karnataka, India.

${ }^{4} \mathrm{~K}$ S Hegde medical college, NITTE (Deemed to be University) Ullal, Karnataka, India.

\section{ABSTRACT}

\section{BACKGROUND}

The removal of microorganism and debris from the root canal system is the prerequisite for success of treatment. This can be achieved by thorough cleaning, shaping and disinfection of the root canal system. The aim of the present study is to investigate the presence of microorganism in primary endodontic infection in South Canara population using PCR technique.

\section{METHODS}

Fifty patients with primary endodontic infection were selected for the study. Access cavity preparation was done followed by working length determination and first sample was collected by placing the paper point near the root apex for $1 \mathrm{~min}$ and immediately the samples were placed in Tris-EDTA buffer solution, stored at $-20^{\circ} \mathrm{C}$, followed by PCR analysis of the sample using specific primers for detection of microorganisms.

\section{RESULTS}

A total of 50 cases with primary endodontic infection were analysed for the presence of microorganism within the root canal system. Percentage analysis was done, and the positive results were obtained only for Porphyromonas endodontalis in $50 \%$ of cases.

\section{CONCLUSIONS}

Porphyromonas endodontalis was the prevalent organism seen in primary endodontic infection in this particular geographic distribution.

\section{KEY WORDS}

Endodontic Infection, Polymerase Chain Reaction, Enterococcus faecalis, Fusobacterium nucleatum, Porphyromonas endodontalis

\begin{abstract}
Corresponding Author:
Dr. Shruthi H. Attavar,

Department of Conservative and Endodontics, $A B$ Shetty Memorial Institute of Dental Sciences, Deralakatte, Mangalore-575018, Karnataka, India.

E-mail:drshruthiattavar@yahoo.in
\end{abstract}

DOI: $10.14260 /$ jemds/2020/249

Financial or Other Competing Interests: None.

How to Cite This Article:

Attavar SH, Hegde MN, Shetty $V$, et al. Molecular method of detection of primary endodontic infection- an ex vivo study. J. Evolution Med. Dent. Sci. 2020;9(14): 1148-1151, DOI: 


\section{BACKGROUND}

The success and failure of root canal treatment is mainly dependent on the presence of microorganisms, their virulence factor, and their pathogenicity. ${ }^{1}$ The role of these bacteria in induction of periradicular disease have been well recorded in both animal and human studies. ${ }^{2}$ Bacteria play an essential role in the initiation and perpetuation of pulpal and periradicular diseases, the elimination of the source of infection is considered paramount in root canal therapy. The oral microbiota has $>400$ bacterial species. However only few species have the ability to colonize and induce periradicular disease. The species most commonly isolated from root canal infection is the Fusobacterium, Prevotella, Porphyromonas, Eubacterium, Peptostreptococcus, Propionibacterium, Actinomyces and Streptococcus. ${ }^{3}$

Despite of the bacterial diversity seen in the necrotic root canals the detection and identification of these microorganism have been very difficult. The majority of the bacterial species of endodontic infection are anaerobic in nature, fastidious in their growth hence become uncultivable and this organism becomes difficult to be identified and can contribute to disease progressive. ${ }^{4}$

The PCR process was introduced by Kary Mullis in 1983 and ever since has revolutionized the field of molecular biology by being able to amplify as few as one copy of a gene into millions to billions of copies of that gene. The impact of PCR on biological and medical research has been remarkable, dramatically speeding the rate of progress of the study of genes and genomes. Molecular method of detection of endodontic microorganism using the 16SrDNA gene in the newer tool for identification of bacterial phylogeny. PCR is a highly sensitive method which can even amplify even a low quantity of DNA into a billion fold a specific known sequence of microbial DNA and allows its detection through electrophoresis. ${ }^{5}$ Hence the focus of current research is to detect the bacterial composition with the root canal system among the South Canara population using PCR technique.

\section{METHODS}

\section{Study Design}

A randomized, double-blind trial was performed involving a sample of 50 patients (sample size was estimated basing on the results obtained by Vianna et al.). Central ethics committee clearance was obtained From NITTE (deemed to be university) NU/CEC/2019/0253. Informed consent was taken from each patient and then the sample collection was done from fifty adult patients who visited the Department for routine endodontic therapy.

\section{Inclusion Criteria}

a. Spontaneous pain.

b. Pain on percussion.

c. Swelling.

d. The teeth included in the study were incisors, canines, premolars, first and second molars.

\author{
Exclusion Criteria \\ a. Previous endodontic therapy. \\ b. Wide open apex. \\ c. Teeth with periodontal pocket. \\ d. Calcified canals. \\ e. Patient who have taken antibiotic therapy during the last \\ months.
}

\section{Sample Collection}

The tooth was isolated using rubber dam, the rubber dam clamp was cleansed with $3 \%$ hydrogen peroxide and decontaminated with $2.5 \%$ sodium hydroxide. Access cavity preparation was done using Endo-Access bur size followed by working length determination using 15 size $\mathrm{K}$ file. The first bacterial sample was collected by placing 25 size paper point near the root apex for $1 \mathrm{~min}$. In case of multirooted tooth the sample was collected from the tooth with larger periapical lesion. A minimum of 5 paper point was used, and the collected samples were immediately placed in Tris-EDTA buffer solution and stored at $-20^{\circ} \mathrm{C} .6$

\section{DNA Extraction}

The extracted DNA samples were quantified by using a Nano Drop Spectrophotometer (Eppendorf). Each sample $(2 \mu \mathrm{L})$ was placed sequentially in the spectrophotometer. The DNA concentration was calculated from the $260 \mathrm{~nm}$ absorbance value for each replicate using the DNA-50 settings. The software automatically calculated the DNA concentration in $\mathrm{ng} / \mu \mathrm{L} .^{7}$

\section{Microbial Selection}

In the present study the main three microorganism were selected based on the criteria

1. The microorganism frequently isolated from the necrotic pulp - Fusobacterium nucleatum.

2. Microorganism with symptomatic endodontic infection Porphyromonas endodontalis.

3. The microorganisms from failed root canal treatmentEnterococcus faecalis. ${ }^{8}$

\section{Microbial Detection (Polymerase Chain Reaction- PCR 16S rDNA)}

Reference bacteria strains which were used in the present study are Enterococcus faecalis (ATCC 4034), Fusobacterium nucleatum (ATCC 25586), Porphyromonas endodontalis (ATCC 35406). ${ }^{9}$

\section{PCR Amplication}

PCR was performed in a thermocycler containing 5 microliter of aliquots, 1 microliter of primer, 5 microliter of primer, 5 microliter of PCR buffer, 1.25 units of taq polymerase and 0.2 $\mathrm{mm}$ of DNTP. The thermocycling conditions of each organisms have been mentioned above in table $1 .{ }^{9}$ 


\section{Gel Electrophoresis}

The amplified product was analysed in 2\% agarose gel electrophoresis in TAE buffer followed by staining of the gel with $0.5 \mathrm{~g}$ of ethidium bromide for $30 \mathrm{~min}$ and flushed with water for $20 \mathrm{~min}$. The anode and cathode electrode were connected at the two ends and electrophoresis were performed at $4 \mathrm{v} / \mathrm{cm}$. A $100 \mathrm{~b}$ p DNA ladder served as a molecular weight marker. The documentation and analysis were done using a gel doc. 10

\section{RESULTS}

A total of 50 cases with primary endodontic infection were analysed using the PCR technique with 16S r DNA specific primer the percentage analysis was done, positive results were obtained with only one organism i.e. Porphyromonas endodontalis.

\begin{tabular}{|c|c|c|c|}
\hline $\begin{array}{c}\text { Target } \\
\text { Bacteria }\end{array}$ & $\begin{array}{c}\text { Amplicon } \\
\text { Size }\end{array}$ & Primers & Cycles \\
\hline $\begin{array}{l}\text { Enterococcus } \\
\text { faecalis }\end{array}$ & $138 \mathrm{bp}$ & $\begin{array}{l}\text { Forward: CCG AGT GCT } \\
\text { TGC ACT CAA TTG G/ } \\
\text { Reverse: CTC TTA TGC } \\
\text { CAT GCG GCA TAA AC }\end{array}$ & $\begin{array}{l}\text { Initial denaturation at } 95^{\circ} \mathrm{C} \\
\text { for } 2 \text { min and } 36 \text { cycles of } \\
95^{\circ} \mathrm{C} \text { for } 1 \mathrm{~min}, 57^{\circ} \mathrm{C} \text { for } 1 \mathrm{~min} \\
72^{\circ} \mathrm{C} \text { for } 1 \mathrm{~min} \text {, and a final } \\
\text { step } 72^{\circ} \mathrm{C} \text { for } 7 \text { min }\end{array}$ \\
\hline $\begin{array}{c}\text { Fusobacterium } \\
\text { nucleatum }\end{array}$ & $1000 \mathrm{bp}$ & $\begin{array}{c}\text { Forward: AGT AGC ACA } \\
\text { AGG GAG ATG TAT G/ } \\
\text { Reverse: CAA GAA CTA } \\
\text { CAA TAG AAC CTG A }\end{array}$ & $\begin{array}{l}\text { Initial denaturation at } 95^{\circ} \mathrm{C} \\
\text { for } 5 \text { min and } 30 \text { cycles of } \\
94^{\circ} \mathrm{C} \text { for } 30 \mathrm{~s}, 40^{\circ} \mathrm{C} \text { for } 1 \mathrm{~min} \text {, } \\
72^{\circ} \mathrm{C} \text { for } 2 \mathrm{~min} \text {, and a final } \\
\text { step } 72^{\circ} \mathrm{C} \text { for } 10 \mathrm{~min}\end{array}$ \\
\hline $\begin{array}{l}\text { Porphyromonas } \\
\text { endodontalis }\end{array}$ & $672 \mathrm{bp}$ & $\begin{array}{l}\text { Forward: GCT GCA GCT } \\
\text { CAA CTG TAG TC/ } \\
\text { Reverse: CCG CTT CAT } \\
\text { GTC ACC ATG TC }\end{array}$ & $\begin{array}{l}\text { Initial denaturation at } 95^{\circ} \mathrm{C} \\
\text { for } 2 \text { min and } 36 \text { cycles of } \\
94^{\circ} \mathrm{C} \text { for } 30 \mathrm{~s}, 58^{\circ} \mathrm{C} \text { for } 1 \mathrm{~min} \text {, } \\
72^{\circ} \mathrm{C} \text { for } 2 \mathrm{~min} \text {, and a final } \\
\text { step } 72^{\circ} \mathrm{C} \text { for } 10 \mathrm{~min}\end{array}$ \\
\hline \multicolumn{4}{|c|}{$\begin{array}{c}\text { Table I. The Primers and Thermocycling Parameters } \\
\text { Used for Identification of Bacterial Species }\end{array}$} \\
\hline
\end{tabular}

\begin{tabular}{|cccc|}
\hline Target Bacteria & $\begin{array}{c}\text { Total No. of } \\
\text { Sample }\end{array}$ & $\begin{array}{c}\text { No. of Samples with } \\
\text { Positive Results }\end{array}$ & $\%$ \\
\hline $\begin{array}{c}\text { Fusobacterium nucleatum } \\
\text { Porphyromonas } \\
\text { endodontalis }\end{array}$ & 50 & 0 & 0 \\
Enterococcus faecalis & 50 & 25 & $50 \%$ \\
\hline \multicolumn{2}{|c|}{ Table 2. Bacterial Percentage for 50 Target Specific Primers } \\
in Samples from Primary Endodontic Infection
\end{tabular}

\section{DISCUSSION}

Black pigmented bacteria are gram negative rods which are most commonly present in the oral cavity, respiratory and intestinal tract (Bogen and Slots). ${ }^{11}$ These organisms serve a challenge for traditional culture technique because they are obligate anaerobes which require a strict anaerobic culturing method. Moreover, these pathogens produce black and identical colonies in culture plate which becomes very difficult to identify these organisms. Therefore, PCR have been a useful tool to directly survey the clinical samples without isolating these organisms from pure culture. ${ }^{12}$

\section{Major Factors Influencing the Composition of Bacterial Flora}

1. The origin of infection.

2. The ecological conditions in the infected root canal.

3. The host defense mechanisms.
The micro flora of endodontic have originated from the oral cavity most of the species are similar to that of periodontal pockets. The microorganisms enter the root canal through the dentinal tubules makes the pulp necrotic reduces the oxygen tension. This low redox potential, favours the growth of anaerobic microbes. ${ }^{13}$

In the present study Nanodrop system was used to quantify the amount of DNA in the samples. This device combines the property of fiber optic system and natural surface tension therefore used to measure the amount of DNA, RNA, protein and dye. The identification of bacterial species of endodontic infection using PCR is the focus of current research. The PCR technique can readily identify the slow growing and uncultivable bacterial species and $16 \mathrm{~S} \mathrm{r}$ DNA represents the most. ${ }^{14}$

Porphyromonas endodontalis have been isolated from endodontic infection in prevalence of $0-7 \%$. In the present study (table 2) Porphyromonas endodontalis was found in $50 \%$ of the cases which shows a high prevalence of these organisms in the particular geographic area. This can be in accordance with the study done by Pontera et al who detected Porphyromonas endodontalis in $16 \%$ of cases by direct immunofluorescence assay. Mark et al also found the association of these organisms in $36 \%$ of the infected root canal cases. 15

There was no Enterococcus faecalis detected in the present study because all cases included were primary cases of endodontic infection and E. faecalis is the predominant organism of refractory cases. Similarly, Fusobacterium nucleatum are common organisms of interappointmental flare ups hence these may be the reason that these microorganisms were not detected in the present study. ${ }^{16} \mathrm{~A}$ study done by Markkar et al showed the association of $\mathrm{P}$ endodontalis in $35 \%$ of the cases with pain and $24 \%$ of the cases with swelling. however, in the present study $\mathrm{P}$ endodontalis was found $20 \%$ in cases with swelling and 30\% of the cases with acute periradicular lesion. ${ }^{17}$

\section{CONCLUSIONS}

Within the limitation of this study we conclude that Porphyromonas endodontalis is the prevalent organism seen in root canal infection in the particular geographic area.

\section{REFERENCES}

[1] Endo MS, Signoretti FGC, Marinho ACS, et al. PCR identification of endodontic pathogens and DNA quantification in samples from teeth with post treatment apical periodontitis. Clinical and Laboratorial Research in Dentistry 2014;20(4):197-208.

[2] Dudeja PG, Dudeja KK, Srivastava D, et al. Microorganisms in periradicular tissues: Do they exist? A perennial controversy. J Oral Maxillofac Pathol 2015;19(3):356-63.

[3] Gomes BPFA, Pinheiro ET, Gade-Neto CR, et al. Microbiological examination of infected dental root canals. Oral Microbiol Immunol 2004;19(2):71-6. 
[4] Siqueira JF Jr, Rocas IN. Microbiology and treatment of acute apical abscesses. Clinical Microbiology Reviews 2013;26(2):255-73.

[5] Janda JM, Abbott SL. 16S rRNA gene sequencing for bacterial identification in the diagnostic laboratory: pluses, perils and pitfalls. J Clin Microbiol 2007;45(9):2761-4.

[6] Blome B, Braun A, Sobarzo V, et al. Molecular identification and quantification of bacteria from endodontic infections using real-time polymerase chain reaction. Oral Microbiol Immunol 2008;23(5):384-90.

[7] Rolph HJ, Lennon A, Riggio MP, et al. Molecular identification of microorganisms from endodontic infections. J Clin Microbiol 2001;39(9):3282-9.

[8] Cheung GS, Ho MW. Microbial flora of root canal-treated teeth associated with asymptomatic periapical radiolucent lesions. Oral Microbiol Immunol 2001;16(6):332-7.

[9] Endo MS, Ferraz CCR, Zaia AA, et al. Quantitative and qualitative analysis of microorganisms in root-filled teeth with persistent infection: monitoring of the endodontic retreatment. Eur J Dent 2013;7(3):302-9.

[10] Siqueira JF Jr, Rocas IN, Rosado AS. Investigation of bacterial communities associated with asymptomatic and symptomatic endodontic infections by denaturing gradient gel electrophoresis fingerprinting approach. Oral Microbiol Immunol 2004;19(6):363-70.

[11] Cao H, Qi Z, Jiang H, et al. Detection of Porphyromonas endodontalis, Porphyromonas gingivalis and Prevotella intermedia in primary endodontic infections in a Chinese population. Int Endod J 2012;45(8):773-81.

[12] Bogen G, Slots J. Black-pigmented anaerobic rods in closed periapical lesions. Int Endod J 1999;32(3):204-10.

[13] Hohne C, Neumann D, Jentzsch M. Antimicrobial activities of black-pigmented Gram-negative anaerobes. FEMS Immunology and Medical Microbiology 1993;6(23):235-40.

[14] Haque KA, Pfeiffer RM, Beerman MB, et al. Performance of high-throughput DNA quantification methods. BMC Biotechnol 2003;3:20.

[15] Pantera EA, Zambon JJ, Shih-Levin M. Immunofluorescence for the detection of bacteroids species in human dental pulp. Journal of Enddoontics 1988;14(5):218-23.

[16] De Paz Villanueva LEC. Fusobacterium nucleatum in endodontic flare-ups. Oral Surg Oral Med Oral Pathol Oral Radiol Endod 2002;93(2):179-83.

[17] Makkar S, Nissan R, Wilkinson D, et al. Porphyromonas endodontalis and symptoms from teeth with endodontic infections. Journal of Endodontics 1999;25(4):283. 